\title{
NOTES
}

\section{PRODUCT MARKET DEFINITION UNDER THE SHERMAN AND CLAYTON ACTS}

The allegation of lessened competition necessary to support charges under several of the antitrust provisions must be tested with reference to a market which defines where and in what this competition exists. ${ }^{1}$ Several recent cases have suggested, for the first time in the reported opinions, that the relevant market to be examined in determining whether competition has been affected may vary depending on which of the antitrust provisions is in question. ${ }^{2}$ More particularly, it has been suggested that the relevant market under section 7 of the Clayton Act $^{3}$ differs from that under section 2 of the Sherman Act ${ }^{4}$ with respect to what products are included in the market.

This Note will examine the legislative history of section 7 of the Clayton Act to determine if any changes in market delineation standards from those of the earlier Sherman Act were intended by the later act's authors, compare the differences between the relevant markets delineated in cases under the two acts, and analyze the reasons for and the propriety of those variations which appear to exist.

\section{Legislative History of Section 7}

\section{A. Drafting and Amendment}

In 1914 Congress passed the Clayton Act with the declared purpose of invalidating certain trade practices against which, "singly and in themselves," the Sherman Act was not a sufficient bar. ${ }^{5}$ This was the specific intention of the House Judiciary Committee, which wrote the Clayton Bill. ${ }^{6}$

The commentators, looking on section 7 in its final form, have not concluded that Congress intended to create a new definition of product

1 See, e.g., Atr'y Gen. Nat'i Comm. Antitrust Rep. 4448 (1955).

2 See United States v. E. I. du Pont de Nemours \& Co., 353 U.S. 586, 593-95 (1957); Crown Zellerbach Corp. v. FTC, 296 F.2d 800, 814-15 (9th Cir. 1961), petition for cert. filed, 30 U.S.L. WEEK 3297 (U.S. March 16, 1962); United States v. Bethlehem Steel Corp., 168 F. Supp. 576, 593 n.36 (S.D.N.Y. 1958).

364 Stat. 1125 (1950), 15 U.S.C. \$ 18 (1958).

426 Stat. 209 (1890), as amended, 15 U.S.C. $\$ 2$ (1958).

5 S. Rep. No. 698, 63d Cong., $2 d$ Sess. 1 (1914).

6 51 Cong. REC. 9070 (1914) (remarks of Rep. Webb in opening the House discussions on the Clayton Bill). 
market for use under the Clayton Act. ${ }^{7}$ But a careful reading of the legislative history suggests that the authors of the original bill are quite likely to have sought to meet the weaknesses of the Sherman Act in this very way.

As originally reported to the House by the Judiciary Committee on May 6, 1914, the relevant portion of section 7 (then numbered section 8) reads as follows:

$[N]$ o corporation engaged in commerce shall acquire, directly or indirectly, the whole or any part of the stock or other share capital of another corporation engaged also in commerce, where the effect of such acquisition is to eliminate or substantially lessen competition between the corporation whose stock is so acquired and the corporation making the acquisition, or to create a monopoly of any line of trade in any section or community.

The first clause-concerning the substantial lessening of competition - sheds little light on product market delineation; here the focus, both in the bill and in the final act, ${ }^{9}$ was on competition between the acquired and acquiring firms. But the second clause-dealing with the effect on the market as a whole of the creation of monopoly - can only have strengthened the test of the Sherman Act by means of a changed market definition or by removing the requirement of intent and confining the inquiry to anticompetitive effects.

The subsequent legislative history of section 7 , however, suggests that the draftsmen of the bill did not conceive of that section as not requiring proof of intention. In the course of debates ${ }^{10}$ it was objected that the Clayton Act's test, in inquiring into effects, was weaker than the Sherman Act as interpreted in Northern Sec. Co. v. United States, ${ }^{11}$ wherein the Supreme Court had held that in order to show a violation of section 1

7 See, e.g., Martin, Mergers and the Clayton Act $20-56$ (1959); Mann \& Lewyn, The Relevant Market Under Section 7 of the Clayton Act: Two New CasesTwo Different Views, 47 VA. L. REv. 1014 (1961); cf. Handler \& Robinson, A Decade of Administration of the Celler-Kefauver Act, 61 Colum. L. REv. 629 (1961).

8 H.R. REP. No. 627, 63d Cong., 2d Sess. 3 (1914). (Emphasis added.)

\& S. Doc. No. 584, 63d Cong., $2 d$ Sess. 8 (1914). The words "substantially lessen" are meaningful without an assumption that competition in the market as a whole was meant. Nor is it necessary, in order to give them meaning, to require that the area in which the merging firms competed was a substantial part of the firms' business. It has been suggested that the word "substantially" was intended to deal with the situation where only part of the stock of a competitor was acquired, giving the acquirer less than complete control, and a degree of control which was not in each instance related in the same way to the proportion of stock acquired. See Martin, Mergers and the Clayton Act 47 (1959). A discussion in American Crystal Sugar Co. v. Cuban-American Sugar Co., 152 F. Supp. 387 (S.D.N.Y. 1957), aff'd, 259 F.2d 524 (2d Cir. 1958), is illustrative. The district court said, "[T] here has been no proof that defendant's acquisition of stock has so far resulted in a lessening of competition. The defendant so far has only a minority interest in the voting stock of the plaintiff [the acquired] company.". The defendant's purchase of the plaintiff's stock was, however, admitted to be but one step in its program of lessening competition. Id. at 395.

1051 Cong. REC. 9271 (1914); see id. at 14464.

11193 U.S. 197, 327, 332 (1904). 
of the Sherman Act it was necessary only to prove that the power to restrain trade had been created, not that it had been exercised. The bill's proponents would have been expected to raise the argument that proof of intent was not required under these circumstances had they so conceived of the section. ${ }^{12}$ Instead, they pointed to the strict language of the first clause of the proposed section ${ }^{13}$ and, finally, amended the bill to include within its prohibitions stock acquisitions "where the effect of such acquisition may $b e$. . . to restrain . . . commerce in any section or community, or tend to create a monopoly of any line of commerce." 14

By contrast, the question of relevant market under the section was not only not discussed but was never-insofar as product market was concerned-called in issue. When the Senate sought to strike the words "in any section or community," on the ground that they were either surplusage or void as relating to intrastate commerce, the phrase was struck without any meaningful discussion; ${ }^{15}$ however, it reappeared after conference, no longer modifying the monopoly phrase, but now describing acquisitions whose effect was to restrain commerce. ${ }^{16}$

Hence, by a process of elimination, it seems that if section 7 , as written by the House Committee, reached acquisitions which would have been legal under the Sherman Act, it must have done so by adopting a different definition of the geographic or product market or both. There is, moreover, some reason to find in the language of section 7 , as enacted, an intention to differentiate the market for that section from that which had been used under the Sherman Act. As has been noted, the Claytor Act spoke in terms of "any line of commerce" and "any section or community." The Sherman Act prohibited combinations resulting in monopolization of "any part" of interstate commerce. In Standard Oil Co. v. United States, ${ }^{17}$ that phrase was stated to have "both a geographical and a distributive significance." 18 However, Sherman Act cases had generally dealt with a geographic market which was nationwide. ${ }^{10}$ The words "in any section or community" clearly refer to a market that is less than nationwide.

The intended effect of the phrase "in any line of commerce" is not as clear. Possibly the intention with respect to the product market paralleled

12 Compare H.R. REP. No. 1191, 81st Cong., 1st Sess. 8 (1949) (dealing with the 1950 amendments to $\$ 7)$.

1351 Cong. Rec. 9271 (1914).

14 S. Doc. No. 584, 63d Cong., 2d Sess. 8 (1914). (Emphasis added.) See 51 Cong. Rec. 14464 (1914).

15 S. Rep. No. 698, 63d Cong., 2d Sess. 46 (1914). During the Senate debates a motion to eliminate in its entirety this clause relating to creation of a monopoly was rejected. 51 CoNG. REc. 14462 (1914).

16 S. Doc. 584, 63d Cong., 2d Sess. 8 (1914).

17221 U.S. 1 (1911).

18 Id. at 61.

19 See, e.g., United States v. American Tobacco Co., 221 U.S. 106, 155-75 (1911); Standard Oil Co. v: United States, 221 U.S. 1 (1911); United States v. E. I. du Pont de Nemours \& Co., 188 Fed. 127, 145 (C.C.D. Del. 1911), modified, 273 Fed. 869 (C.C.D. Del. 1921). But see Addyston Pipe \& Steel Co. v. United States, 175 U.S. 211 (1899). 
that with respect to the geographic market, in the hopes that a narrower market would effectuate the purposes of the Clayton Act's antimerger provisions. A narrowly defined market, however, does not necessarily lead in the direction of invalidation of a merger. When the products of competing firms are identical, the more narrowly defined the market is, the greater their share will be, and the less likely the merger to survive. However, in any case involving the merger of alleged competitors, the market must be defined broadly enough to encompass the products of both firms. ${ }^{20}$ Thus Congress could have most strengthened the act by providing that the boundaries of the market fluctuate with the type of acquisition under consideration. Some suggestion of this intention may be found in the requirement that anticompetitive effects be tested not in the, but in any line of commerce. At any rate, the implication is strong that some effect different from that of the Sherman Act was intended; its phrase "any part" of commerce could have been retained to describe the distributive element, but was not.

\section{B. Judicial Construction}

In the years after the passage of the Clayton Act, the interpretations of its section 7 and of the Sherman Act in a sense converged. First, the courts read into section 7 a requirement that the acquisition have lessened competition "to such a degree as [would] injuriously affect the public." 21 This test required by implication that the competition between the merging firms had been substantial in terms of the market as a whole; otherwise the public could not be injured.22 Second, Sherman Act cases began to deal with more limited geographic markets. ${ }^{23}$

Product market definition problems were important in two section 7 cases under the 1914 act, in both of which the market was narrowly defined. In FTC v. Thatcher $M f g$. Co., ${ }^{24}$ a manufacturer of milk bottles had acquired a manufacturer of fruit juice and soft drink bottles and fruit jars. The Third Circuit, finding the relevant market to be milk bottles, rather than glass bottles and jars in general, held that the acquisition did not result in a prohibited effect on competition. In International Shoe Co. v. FTC, ${ }^{25}$ the Supreme Court took a similarly narrow view of the relevant

20 See, e.g., American Crystal Sugar Co. v. Cuban-American Sugar Co., 259 F.2d 524, 529 (2d Cir. 1958).

21 International Shoe Co. v. FTC, 280 U.S. 291, 298 (1930). In United States v. Republic Steel Corp., 11 F. Supp. 117, 123 (N.D. Ohio 1935), a $\$ 7$ case, the court specifically stated that it was applying Sherman Act criteria.

22 See Temple Anthracite Coal Co. v. FTC, 51 F.2d 656 (3d Cir. 1931); V. Vivaudou, Inc. v. FTC, 54 F.2d 273 (2d Cir. 1931); United States v. Republic Steel Corp., supra note 21, at 124-25.

23 See United States v. Columbia Steel Co., 334 U.S. 495, 519-20 (1948); Indiana Farmer's Guide Publishing Co. v. Prairie Farmer Publishing Co., 293 U.S. 268, 278-79 (1934); cf. United States v. Paramount Pictures, Inc., 334 U.S. 131, 171-74 (1948).

245 F.2d 615 (3d Cir. 1925), modified sub. nom. FTC v. Western Meat Co., 272 U.S. 554 (1926).

25280 U.S. 291 (1930). 
market, finding that two lines of comparably priced men's dress shoes were not in competition because of differences in style, construction, and marketing techniques. Once again, the result of narrow market definition was to make the acquisition valid under section $7 .{ }^{26}$ The markets defined in these two cases appear to be narrower than those used under Sherman Act cases of the same period, ${ }^{27}$ although the opinions do not articulate either an intention to apply a different market definition or any reason for such a difference. Interestingly, the result of this apparent difference is to render the Clayton Act's provisions less rather than more stringent than those of the Sherman Act, despite a clear congressional intention to the contrary.

\section{The 1950 Amendments}

The declared purpose of the 1950 amendments of the Clayton Act was "to cope with monopolistic tendencies in their incipiency and well before they have attained such effects as would justify a Sherman Act proceeding," 28 and "to limit future increases in the level of economic concentration resulting from corporate mergers and acquisitions." 28

Although the main thrust of the 1950 amendments to section 7 was to include asset as well as stock acquisitions within the section's scope, ${ }^{30}$ the section was further changed to prohibit either sort of acquisition "where in any line of commerce in any section of the country, the effect of such acquisition may be substantially to lessen competition, or to tend to create a monopoly." 31 The test of a restraint of commerce in any section or community was omitted entirely. Thus, the phrase "in any line of commerce" was retained to define the product market and was applied to the lessening of competition as well as the tendency to create a monopoly. The geographic market definition, changed to relate to "any section of the country," was likewise applied to both these effects.

The legislative history of the 1950 amendments is not illuminating on the question of whether the section 7 market (or the similarly defined section 3 market ${ }^{32}$ ) was intended to differ in any way from the markets under the Sherman Act or the 1914 version of the Clayton Act. The meaning of the qualifying phrases was discussed only in the most general terms. ${ }^{33}$

$26 I d$. at 298-99.

27 See, e.g., United States v. Aluminum Co. of America, 148 F.2d 416 (1945); United States v. Corn Prods. Ref. Co., 234 Fed. 964 (S.D.N.Y. 1916), appeal dismissed, 249 U.S. 621 (1919).

28 S. Rep. No. 1775, 81st Cong., 2d Sess. 4-5 (1950).

$29 \mathrm{Id}$. at 3.

30 Handler \& Robinson, supra note 7, at 652 .

3164 Stat. 1125 (1950), 15 U.S.C. § 18 (1958).

32 Section 3 of the Clayton Act prohibits exclusive dealing or tying contracts where the effect "may be substantially to lessen competition or to tend to create a monopoly in any line of commerce." 38 Stat. 731 (1914), 15 U.S.C. \$ 14 (1958).

33 The House Judiciary Committee, for example, stated that "the test of substantial lessening of competition or tending to create a monopoly is not intended to be applicable only where the specified effect may appear on a Nation-wide or industry- 
In the committee hearings George Van Camp \& Sons Co. v. American Can $\mathrm{Co}^{34}$ was cited to demonstrate that any line of commerce means any line of commerce. But that case determined only that the effect of a price discrimination in lessening competition need not be shown in the line of commerce in which the discriminator was engaged and that the line of commerce affected need not be "a large part of the business of any of the corporations involved in the acquisition." 35 Although the House Judiciary Committee report approved International Shoe ${ }^{36}$ with respect to its holding that a substantial lessening of competition, to be illegal, must be in the market as a whole and not merely between the acquired and acquiring companies, ${ }^{37}$ it should not readily be concluded that this approval extended to the market analysis used in that case. This seems particularly true in the light of the telling dissent of Justices Stone, Holmes, and Brandeis, which showed the doubtful economic validity of the analysis as applied to the facts of International Shoe itself. ${ }^{38}$

\section{Conclusion}

An examination of the legislative history of section 7 of the Clayton Act, both as originally enacted and as amended in 1950, reveals no articulated attempt to provide market definition standards different from those under the Sherman Act. Nevertheless, it seems likely that Congress, in drafting the 1914 act, intended to effect some change in market definition. This likelihood is supported by the facts that (1) different market-defining language was used, (2) at least as to geographic market, this language clearly defined a market narrower than that which had been used in previous Sherman Act cases, and (3) unless this language defined a market different from that under the Sherman Act, the standard of illegality relating to the creation of a monopoly would have been of little effect as originally proposed.

The history of the 1950 amendments is even less illuminating. Nevertheless, it seems fair to say that the narrow market of International Shoe was not there enacted into law. As to the more difficult question, it seems

wide scale. The purpose of the bill is to protect competition in each line of commerce in each section of the country." H.R. REP. No. 1191, 81st Cong., 1st Sess. 8 (1949). In discussing the changed geographic market definition, the Senate Committee stated that the elimination of the word "community" was specifically intended to rule out the testing of the anti-competitive effects of a merger in any area such as a small town. S. REP. No. 1775,81 st Cong., 2 d Sess. 4 (1950). The phrase "section of the country," it was stated, could not be rigidly defined, although certain broad standards could be set forth to guide the courts and the Commission in their interpretation. Id. at 5-6. The Senate Committee approved the definition of the market set forth by the Supreme Court in the Standard Stations case, Standard Oil Co. v. United States, 337 U.S. 293 (1949), in terms of the "area of effective competition."

34278 U.S. 245 (1929). See Hearings on H.R. 2739 Before a Subcommittee of the Senate Committee on the Judiciary, 81st Cong., 1st \& 2d Sess. 192 (1949-50).

35 S. REp. No. 1775, 81st Cong., 2d Sess. 5 (1950).

36 International Shoe Co. v. FTC, 280 U.S. 291 (1930).

37 H.R. Rep. No. 1191, 81st Cong., 1st Sess. 7 (1949).

38280 U.S. at 304-05. The court's holding is all the less meaningful in that the opinion also grapples with the "failing company" doctrine. See id. at 299-303. 
impossible to demonstrate that the legislative intention was clearly either to create a market definition different from that existing under the Sherman Act or to require that the Sherman Act standard be applied under section 7. In fact, it seems difficult to show that market definition was considered at all in any meaningful way.

\section{Market Definition in the Courts}

To the economist, the concept of a market is stated in terms of the behavior of buyers and sellers: "[T] wo products belong in the same market if a small change in price (or product) causes a significant diversion in a relatively short time of the buyers' purchases or the sellers' production from one product to another." 39 The courts have somewhat limited the first part of this definition by including in a single market only those products which are also functionally interchangeable with the products sought to be placed in the market. Both functional interchangeability and production flexibility have been examined in Sherman and Clayton Act cases requiring a delineation of the relevant market. It is necessary, then, to examine the cases to determine whether these theories of market definition have been differently applied under the two acts.

\section{A. Production Flexibility}

In United States v. Columbia Steel Co., ${ }^{40}$ it was charged that United States Steel, a producer of rolled steel products, had restrained commerce under the Sherman Act by acquiring Consolidated Steel, a purchaser of steel plates and shapes, a type of rolled steel product. Because rolled steel producers can make other products interchangeably with shapes and plates, the Court concluded that the relevant market for testing the effects of the acquisition was the market for all rolled steel products-although no actual shifts in production were shown. ${ }^{41}$

This interpretation of production flexibility does not appear to be economically significant in terms of market delineation for two reasons. First, Columbia Steel considered only the technological feasibility of production shifts, not whether such shifts occurred in actual practice. But it is only "where producers can and $d o$ produce several products interchangeably [that] the capacity currently devoted to one of those products understates the amount that should fairly be deemed to be 'in' the market." 42 Second, the economic concept of cross-elasticity of supply as a definition of what products are included in the market is based on shifts in production resulting from changes in price. ${ }^{43}$ It hardly seems applicable when

39 Kaysen and Turner, ANtitrust Policy: An Economic and Legat ANalysis 27-28 (1959).

40334 U.S. 495 (1948).

41 Id. at $510-11$.

42 KAYSEN AND TURNER, op. cit. supra note 39, at 134. (Emphasis added.)

43 See text accompanying note 39 supra. 
the shift is due, instead, to the elimination of a potential purchaser through its acquisition by the shifting company's competitor. 44

Columbia Steel's interpretation of production flexibility as a marketdefining factor was emphatically rejected by lower courts in three section 7 cases : Crown Zellerbach Corp. v. FTC, ${ }^{45}$ United States v. Bethlehem Steel Corp., ${ }^{46}$ and United States $v$. Brown Shoe Co. ${ }^{47}$ Two explanations were given. One was that Columbia Steel was a proceeding under the Sherman Act and therefore not determinative of the section 7 market. No reasons were given for this distinction, nor was any authority offered in support of the implicit holdings that the relevant market definitions under the two acts might properly differ. The other basis of the decisions was that although production flexibility was a theoretical possibility, producers of one sort of goods did not in fact shift production to other goods. Thus, in Bethlehem, the court refused to expand the relevant market because "in practice steel producers have not been quick to shift from product to product in response to demand. Moreover, the evidence establishes that the continuing relationships between buyers and sellers in the steel industry make such shifts unlikely." 48 This language was quoted with approval by the Ninth Circuit in Crown Zellerbach after a finding that it was not the practice of sellers to shift production because they had established customers and were selling through brokerage channels.49 Likewise, in Brown Shoe, men's, women's, and children's shoes were held to be separate lines of commerce because, although certain machinery is readily adaptable to the production of each of these lines, shoe manufacturers who produce all three lines normally do so in separate plants. ${ }^{50}$

\section{B. Functional Interchangeability}

Whereas production flexibility, with its emphasis on the producer, has been infrequently employed in market delineation, functional interchangeability or other concepts describing the market from the consumer's standpoint have been the typical criteria for product market definition under both the Clayton and Sherman Acts.

44 Production flexibility caused by such a foreclosure of a part of the market is relevant only to the protection of competitors of the alleged violator, not to the protection of competition in the market for its product. Whether or not protection of competitors in and of itself (as distinguished from a means to protection of competition) is or should be a factor in determining if competition has been substantially lessened or monopolization taken place, it is not a factor in determining the boundaries of the relevant product market; if producers can easily shift production to products other than the one allegedly monopolized, the "monopolist" may find it easier to occupy the entire field.

45296 F.2d 800 (9th Cir. 1961), petition for cert. filed, 30 U.S.L. WEEK 3297

(U.S. March 16, 1962).

46168 F. Supp. 576 (S.D.N.Y. 1958).

47179 F. Supp. 721 (E.D. Mo. 1959), prob. juris. noted, 363 U.S. 825 (1960).

48168 F. Supp. at 592 .

49296 F.2d at 812-13.

50179 F. Supp. at 731-32, 
In Sherman Act cases, ${ }^{51}$ the rule for determination of the relevant market was first enunciated by Judge Learned Hand in United States $v$. Corn Prods. Ref. Co.62 Products physically distinct from but functionally interchangeable with the allegedly monopolized product must be included in the relevant product market unless the allegedly monopolized product possesses a substantial advantage in either consumer preference or cost of production. ${ }^{53}$ The economic concept of cross-elasticity of demand was introduced into market delineation by the Supreme Court in TimesPicayune Publishing Co. v. United States, ${ }^{54}$ in which the relevant market was limited to newspaper advertising despite the defendant's contention that it should include other means of communication. ${ }^{55}$ The Court reasoned that a reasonable variation in price would cause only a limited number of buyers to change from newspaper to other mass media, or viceversa; hence the cross-elasticity of demand was small and the markets distinct. . $^{56}$

The leading Sherman Act monopolization case, United States v. E. I. $d u$ Pont de Nemours \& Co. ${ }^{57}$ (the "Cellophane" case), stated that the relevant market is composed of products that have "reasonable interchangeability for the purposes for which they are produced-price, use and qualities considered." 58 The Court's opinion contains language repeating the admonition of Judge Learned Hand in United States $v$. Aluminum Co. of America ${ }^{59}$ that interindustry competition has no place in defining the market for Sherman Act purposes. But whereas the court

51 Throughout this section of this Note, the discussion will be directed primarily to Sherman Act monopolization cases. There has been little attempt to delimit the relevant market for the Sherman Act merger case. See note 110 infra. In Sherman Act attempt and conspiracy cases a very narrow definition of the relevant market is employed; the market as there defined need not be a market in any meaningful economic sense. See Turner, Antitrust Policy and the Cellophane Case, 70 HARv. L. Rev. 281,290 (1956). Specific intent is required to prove an attempt or conspiracy violation, but the monopoly need have been intended over only some appreciable amount of commerce. United States v. Columbia Steel Co., 334 U.S. 495 (1948); United States v. Yellow Cab Co., 332 U.S. 218 (1947). No showing that the intended monopoly power was achieved is needed to show a violation. United States $\nabla$. Columbia Steel Co., supra at 531-32 (attempt); United States v. Griffith, 334 U.S. 100, 107 n.9 (1948) (conspiracy); American Tobacco Co. v. United States, 328 U.S. 781, 789 (1946) (conspiracy). Therefore, it is not considered whether products physically distinct from, but functionally interchangeable with the product sought to be monopolized are included within the market.

52234 Fed. 964 (S.D.N.Y. 1916), appeal dismissed, 249 U.S. 621 (1919). In Corn Products, monopolization charges were directed against a firm whose market power was in part the result of mergers with its competitors. However, the violation charged was that of monopolization, not combination to monopolize.

53 Id. at 975-77.

54345 U.S. 594 (1953).

55 Id. at $611-12$.

56 Id. at 612 n.31. Defendant-publisher had instituted a "unit plan" for the purchase of advertising space in his two newspapers, under which space in both had to be purchased if space in one-the only morning newspaper in town-was desired. Despite the Court's choosing a narrower market than that urged by defendant, the defense prevailed, since no market dominance or unreasonable restraint was found.

57351 U.S. 377 (1956).

$58 \mathrm{Id}$. at 404.

59 148 F.2d 416 (2d Cir. 1945). 
in Alcoa did not consider competition of aluminum with copper and steel, ${ }^{60}$ the Court in Cellophane confined its market limitation to language. And it continued by saying that it is not "a proper interpretation of the Sherman Act to require that products be fungible to be considered in the relevant market." 61 More specifically, the Court concluded that the relevant market in a suit charging monopolization of cellophane production and sales was made up of all "flexible packaging materials," including brown wrapping paper, wax paper, glassine, polyethelene film, and aluminum foil, ${ }^{62}$ despite the fact that cellophane combined "the desirable elements of transparency, strength and cheapness more definitely than any of the others." ${ }^{83}$

In the most recent Supreme Court case concerned with the Sherman Act market, International Boxing Club v. United States, ${ }^{64}$ the Court restated the reasonable interchangeability test of Cellophane, but placed greater emphasis on its limitation: "price, use, and qualities considered." Thus, the Court was able to conclude that championship and nonchampionship boxing matches were not in the same market-although they might be physically identical, involving the same combatants in the same ringbecause of a sizeable price differential based on consumer preference. ${ }^{65}$ The Court also noted, ${ }^{68}$ by way of dictum, that the market which it had defined met the Clayton Act section 7 market definition test as set forth in United States v. E. I. du Pont de Nemours \& Co. (the "General Motors" case) ${ }^{67}$

The General Motors case contained the first intimation that the relevant market for section 7 purposes might be defined in a manner other than that used in Sherman Act monopolization cases. The Court stated that du Pont, after its acquisition of $23 \%$ of General Motors outstanding stock, enjoyed a "commanding position as General Motors' supplier of automotive finishes and fabrics...." 68 The market delineation issue therefore turned on whether all finishes and fabrics for industrial uses or only "automotive finishes and fabrics" comprised the line of commerce for testing the effects of the acquisition. Without referring to the Cellophane case, which had been decided less than a year before, the Court stated:

60 The district court opinion had placed some weight on interindustry competition. United States v. Aluminum Co. of America, 44 F. Supp. 97, 165, 222-23 (S.D.N.Y. 1941).

61351 U.S. at 394.

62 Id. app. A at 405.

63351 U.S. at 398.

64358 U.S. 242 (1959).

65 Id. at 249-52.

$68 I d$. at $252 \mathrm{n} .8$.

67353 U.S. 586 (1957). General Motors was decided under old \$7, but under the phrase making illegal acquisitions whose probable effect was to tend to create a monopoly in any line of commerce. This standard was found by the court to be applicable to a vertical merger such as took place here, du Pont having purchased an interest in its customer, General Motors. Id. at 590-92.

68 Id. at $588-89$. 
[T] he record shows that automotive finishes and fabrics have sufficient peculiar characteristics and uses to constitute them products sufficiently distinct from all other finishes and fabrics to make them a "line of commerce" within the meaning of the Clayton Act. . . . Thus, the bounds of the relevant market . . . are not coextensive with the total market for finishes and fabrics, but ... with [that of] the automobile industry, the relevant market for automotive finishes and fabrics. ${ }^{69}$

It is not clear whether General Motors attempted to set up standards for determining the section 7 market different from those used under the Sherman Act. However, some subsequent section 7 cases have applied its "peculiar characteristics and uses" test, stating that the reasonable interchangeability test of the Cellophane case is inapplicable to section 7 litigation. Thus, in Bethlehem Steel, ${ }^{70}$ the district court stated that "there can be a substantial lessening of competition with respect to a product whether or not there are reasonably interchangeable substitutes." 71 However, the existence of products effectively substitutable for the various steel product lines found to constitute lines of commerce was considered by the court ${ }^{72}$ and found not to exist.73 A similar exposition was used by the court in Crown Zellerbach ${ }^{74}$ on the authority of Bethlehem Steel, but again the court noted that the contention that there were interchangeable products was "simply not borne out by the facts." 75 Two other section 7 cases which have applied the "peculiar characteristics and uses" test are $A$. G. Spalding \& Bros. v. FTC ${ }^{76}$ and Reynolds Metals Co. ${ }^{77}$ Spalding, in considering the merger of two athletic goods producers who sold chiefly high quality goods for athletic competitions, used a product market which excluded low quality athletic goods used for toys. ${ }^{78}$ Reynolds involved a

$60 \mathrm{Id}$. at 593-95. As noted by the dissent, $i d$. at 650 , the majority failed to specify just what these peculiar characteristics and uses were, mentioning only that du Pont's automotive finish was a great contribution to the automobile industry, id. at $594 \mathrm{n} .12$.

70 United States v. Bethlehem Steel Corp., 168 F. Supp. 576 (S.D.N.Y. 1958). In this case a merger between the second and sixth largest steel companies, both integrated, was attacked by the Government. The court held that the relevant lines of commerce included both lines consisting of certain steel products and a line embracing the entire industry. Id. at 589-95.

71 Id. at 593-94 n.36.

72 Ibid.

${ }^{73}$ Id. at 593.

74 Crown Zellerbach Corp. v. FTC, 296 F.2d 800 (9th Cir. 1961), petition for cert. filed, 30 U.S.L. WEEK 3297 (U.S. March 16, 1962).

75 Id. at 814 .

T0 301 F.2d 585 (3d Cir. 1962).

77 Trade Reg. Rep. \l 28533 (FTC Jan. 21, 1960).

78 A. G. Spalding \& Bros. v. FTC, 301 F.2d 585 (3d Cir. 1962). In both Spalding, id. at 628, and United States v. Bethlehem Steel Corp., 168 F. Supp. 576, 594 (S.D.N.Y. 1958), the courts defined an industrywide line of commerce, in addition to a series of narrower lines as a relevant market. Although common parlance might thus characterize an entire industry, definitions of the phrase "line of commerce" under the Clayton Act have otherwise been confined to products competitively related in 
forward vertical acquisition of a customer, a converter of aluminum florist foil. The relevant market was limited to florist foil, after a discussion of its peculiar characteristics and uses. ${ }^{79}$ The FTC concluded that there were no practical substitutes for florist foil, but went out of its way to state that a question of end-use interchangeability, such as was presented in Cellophane, was not "involved" in Reynolds.

On the other hand, the doctrine of interchangeability has been implicitly adopted in two section 7 cases which applied it without consideration of whether or not relevant market boundaries were to be judged by the same standards in section 7 as in monopolization cases. Thus in American Crystal Sugar Co. v. Cuban-American Sugar Co., ${ }^{81}$ the relevant market was held to include both beet and cane sugar since they were found by the court to be functionally interchangeable. ${ }^{82}$ And in Erie Sand $\mathcal{E}$ Gravel Co. v. FTC, ${ }^{83}$ it was found that pit and bank sand were functionally interchangeable with lake sand, and therefore to be included within the relevant market absent any disparity in freight costs which would have meant that pit and bank sand could not compete in the relevant geographic market. ${ }^{84}$

In the recent decision in Brozen Shoe, ${ }^{85}$ the district court in effect combined the tests of functional interchangeability and peculiar characteristics and uses. The court cited the definitions of relevant markets set forth in both Cellophane and General Motors, ${ }^{86}$ and fixed the boundaries of the market by examining "the practices in the industry, the characteristics and uses of the products, their interchangeability, price, quality and style . . . ." 87 In United States v. Columbia Pictures Corp. ${ }^{88}$ the district

terms of end use, or, less frequently, production flexibility. The FTC in Spalding found that there were competitive relationships among the various individual products. A. G. Spalding \& Bros., Trade Reg. Rep. II 28694 (FTC March 30, 1960). However, it seems unlikely that competition between baseballs and footballs could be more intense than that among different quality lines of one or the other product, and neither the court's nor the FTC's opinion so suggests. The choice of industrywide lines of commerce in these two cases was not significant in terms of the judgments rendered, since in each case the court found a substantial lessening of competition likely within the individual product lines. The broader market thus defined might be significant in the rare case in which the merged firms' lines were concentrated in different sections of this broad market.

79 Trade Reg. ReP. 1128533 , at 37253-54.

$80 \mathrm{Id}$. at 37256.

81259 F.2d 524 (2d Cir. 1958).

82 In another context, the court noted that certain types of consumers showed a preference for cane sugar. However, the court did not feel that this demonstrated an absence of competition between cane and beet sugar, "but only that for the time being as to certain customers one or the other form of the product for one reason or another has forged ahead in the competitive race. ..." Id. at 530.

83291 F.2d 279 (3d Cir. 1961).

$84 I d$. at 281.

85 United States v. Brown Shoe Co., 179 F. Supp. 721 (E.D. Mo. 1959), prob. juris. noted, 363 U.S. 825 (1960).

86 Id. at $729-30$.

87 Id. at 730.

88189 F. Supp. 153 (S.D.N.Y. 1960). 
court considered the two tests "but different verbalizations of the same criterion . . . ."89 It was there stated that section 7 "demands an examination into economic realities. All competition must be considered, including competition faced by the product in question from other products . . . " 00 Thus evidence that feature films were interchangeable with all television programing was held to refute the government's contention that feature films had peculiar characteristics and uses. ${ }^{01}$ This is in contrast with the recent FTC opinion in Union Carbide Corp., ${ }^{92}$ which required the delineation of the relevant market for polyethylene film. Polyethylene film was one of the flexible packaging materials included in the relevant market in the Cellophane case.93 Although the FTC stated that its delineation of the market was in harmony with that of Cellophane, ${ }^{04}$ the market was limited to polyethylene film because of the consumer preference which had been shown to exist for it. ${ }^{95}$ In a dissenting opinion, it was insisted that Union Carbide was controlled by Cellophane, despite the fact that Cellophane was decided under the Sherman Act, since any distinction between the relevant markets under the two acts was "specious." 98

\section{Conclusion}

If the rule of Columbia Steel is law under the Sherman Act, then the relevant product markets under it and the Clayton Act do differ with respect to production flexibility. Nevertheless, the section 7 cases have not

89 Id. at 184.

90 Id. at 183. In context, this did not include interindustry competition, since only television programing was under consideration.

91 Id. at 190-91.

923 Trade Reg. Rep. II 15503 (FTC Sept. 15, 1961).

93 See text accompanying notes $62-63$ supra.

84 The hearing examiner, apparently feeling that Cellophane was not applicable, had held that the relevant market was polyethylene film, based on the General Motors peculiar characteristics and uses test. 3 TRADE REG. REP. 11 15503, at 20371-72. The Commission, however, stated that this narrow market was in harmony with both Cellophane and General Motors. Id. at 20372.

95 Id. at 20372-73. The Commission gave no reason why such consumer preference had not influenced the Court in Cellophane. Once having found this consumer preference, the Commission stated that any competition between polyethylene film and other flexible packaging materials was "inter-product," id. at 20373, apparently alluding to the interindustry dictum in Cellophane. See notes 57-60 supra and accompanying text.

963 Trade Reg. REP. II 15503, at 20382. Nor was the majority emphasis on consumer preference for polyethylene film thought to be determinative; "these minor product advantages with respect to what are essentially competitive products constitute the essence of vital and vigorous competition . . . " and research might nullify the supposed superiority of one product within a short time. Ibid.

Definition of the relevant product market is also necessary under $\S 3$ of the Clayton Act, which prohibits exclusive dealing and tying agreements when the effect of an agreement "may be to substantially lessen competition or tend to create a monopoly in any line of commerce." 38 Stat. 731 (1914), 15 U.S.C. \$14 (1958). Although authority as to the extent of the relevant market under $\$ 3$ is rare, it was suggested in the recent case of Tampa Elec. Co. v. Nashville Coal Co., 276 F.2d 766 (6th Cir.), rev'd on other grounds, 365 U.S. 320 (1960), that the relevant market for $\$ 3$ might be narrower than that for monopolization offenses. See also Mytinger \& Casselberry, Inc. v. FTC, 301 F.2d 534 (D.C. Cir. 1962). 
only failed to enunciate reasons why the test should be differently applied under the two acts, they have shown so convincingly why production flexibility as it was used in Columbia Steel is generally so unsuited to market delineation that it is unlikely that courts today would apply it even in Sherman Act cases. Three considerations produce this prognosis. First, the section 7 cases reflect refinements in product market delineation developed since the 1948 decision in Columbia Steel. Second, that decision runs contrary to the policy of the antitrust laws in that it would sustain actual monopolies on the basis of illusory production flexibility. Third, it does not appear from the opinion that an economically meaningful view of production flexibility-as contrasted with technological potentialitywas presented to the Court in Columbia Steel, as it was in the three section 7 cases.

No such clear difference exists between section 7 and Sherman Act cases with respect to functional interchangeability. Nevertheless, it is possible to draw some general conclusions from the decisions under the two acts and to see in the cases some indication that, on the whole, the relevant market with respect to functional interchangeability is narrower under the Clayton than under the Sherman Act.

Thus, although the "peculiar characteristics and uses" test recently applied in section 7 cases allows consideration of the same elements as the more traditional test of interchangeability ("price, use, and qualities considered") used under both acts, the new test seems to-and, as applied, does-stress the peculiarity of the characteristics and uses of the product rather than its interchangeability with other physically distinct products.

Again, although the two lower court section 7 cases which explicitly reject Cellophane ${ }^{97}$ were not required to do so on their facts-in both Bethlehem Steel ${ }^{98}$ and Crozen Zellerbach, ${ }^{99}$ the courts found that there were in fact no interchangeable products-the relevant markets in both those cases and in General Motors ${ }^{100}$ were much narrower than that used in Cellophane. ${ }^{101}$ On the other hand, American Crystal Sugar ${ }^{102}$ and Erie Sand, ${ }^{103}$ which applied the Cellophane test to section 7 cases, would have been decided in the same way under either test, since the products included in the market used were practically fungible. Thus, although there is no indication in the section 7 cases that interchangeability is completely irrelevant-nor should there be, since the legislative history of the act requires

97351 U.S. 377 (1956).

98168 F. Supp. 576 (S.D.N.Y. 1958).

99296 F.2d 800 (9th Cir. 1961).

100353 U.S. 586 (1957).

$101 \mathrm{~A}$ recent district court case might indicate that in an extraordinary economic situation the General Motors test might produce a broader market than that of Cellophane. See United States v. Koppers Co., 202 F. Supp. 437, 444-46 (W.D. Pa. 1962).

102259 F.2d 524 (2d Cir. 1958).

103291 F.2d 279 (3d Cir. 1961). 
that the market defined be economically meaningful ${ }^{104}$, , none of them showed a willingness to widen the market to the degree suggested in Cellophane.

In addition, although the Cellophane case's broad language may not in fact be applicable to even Sherman Act cases-not only does the inclusion of such different products as paper and aluminum foil in the same market seem to conflict with the case's own doctrine as to the exclusion of interindustry competition, ${ }^{105}$ but International Boxing $C l u b,{ }^{106}$ by its emphasis on consumer preference, may have narrowed the section 2 monopolization market-this does not imply that the markets are identical under the two acts. Moreover, the fact that the Supreme Court in International Boxing $C l u b$, having noted the existence of both the traditional test ${ }^{107}$ and the new test as used in General Motors, ${ }^{108}$ chose to point out that on the particular facts before it the market delineated met either test may indicate a recognition that under other factual situations the markets may be different. ${ }^{109}$

\section{A Rationale for Product Market Differences}

The legislative history of the Clayton Act suggests that the relevant market under that statute may have been designed to differ from that under the Sherman Act. However, although courts have recently shown a tendency to delineate different relevant markets under the two acts, this cannot be attributed to the courts' view of that legislative history.

It may be significant, on the other hand, that Cellophane, the leading Sherman Act case in which a broad market was defined, was a single-entity monopolization, not a merger-combination case. ${ }^{110}$ Since section 7 of the Clayton Act attacks only the latter, the courts may be implicitly drawing a distinction between monopolization and merger. Three considerations appear to justify this distinction: (1) the differences in the severity of the remedies applied; (2) the nature of the conduct involved and the inferences

104 See S. Rep. No. 1775, 81st Cong., 2d Sess. 5-6 (1950).

105 See notes $62-63$ supra and accompanying text.

106358 U.S. 242 (1959).

$107 \mathrm{Id}$. at 252 .

108 Id. at $252 \mathrm{n} .8$.

109 But see Handler \& Robinson, A Decade of Administration of the CellerKefauver Antimerger Act, 61 CoLUM. L. REv. 629, 646 (1961), which draws the conclusion that this statement intimates "that the market is the market whether the case arises under the Sherman or the Clayton Act."

110 Although there have been a number of Sherman Act merger cases, the market was significantly discussed in only two, United States v. Corn Prods. Ref. Co., 234 Fed. 964 (S.D.N.Y. 1916), appeal dismissed, 249 U.S. 621 (1919) and United States v. Columbia Steel Co., 334 U.S. 495 (1948). In Corn Products, the defendants were charged with monopolizing trade in starch and glucose by means of acquiring other companies. The market was narrowly defined to exclude competing products which cost substantially more to produce, or which enjoyed a substantial margin of consumer preference over the allegedly monopolized products. In Columbia Steel, the Court used production flexibility to define a wide market which, by its inclusion of other products, reduced the share controlled by the defendants. 334 U.S. at 510-11. However, it is doubtful if this application of the theory of production flexibility will be of lasting effect. See pp. 873-74 supra. 
of intent that can be drawn from it; ${ }^{111}$ and (3) the general policy of the antitrust laws.

Thus, the remedy of dissolution normally used in individual monopolization cases appears to be much more harsh than the divestiture of a recently acquired, previously independent unit. The internal effect on du Pont of the forced sale of its General Motors holdings ${ }^{112}$ is unlikely to be of the same crippling nature as the forced severance or dissolution of its cellophane department, an integral part of the company, would have been. ${ }^{113}$ Moreover, mergers may be enjoined, and even when a court refuses to grant a preliminary injunction it may, as did the court in Brown Shoe, ${ }^{114}$ require that the businesses of the merging companies be separately conducted so that if divestiture is required in the end, its detrimental effects on the companies may be minimized. ${ }^{115}$

Again, in cases of individual monopolization, the inferences which may be drawn from the defendant's conduct-at least when it would not constitute a restraint of trade under section 1 of the Sherman Act-are unclear..$^{116}$ Not only may monopoly be technologically justified, but it may have been "thrust upon" 117 the monopolist as a result of patent ownership, successful meeting of demand, or a limited market for the monopoly's product. Although it is likewise possible for a merger to be technologically justified, this is less likely; the firms existed independently before the merger, and, particularly as the percentage of the market occupied by the combined firms increases, technological advantages are not, in fact, the normal reason for mergers of competitors. ${ }^{118}$

Finally, the general policy of the antitrust laws is against increasing concentration. ${ }^{119}$ But, whereas section 7 of the Clayton Act is directed against "increases in the level of economic concentration resulting from

111 This theory, insofar as it concerns differences in relevant market definitions under the several Sherman Act violations, is put forward in Turner, Antitrust Policy and the Cellophane Case, 70 HARv. L. REv. 281 (1956).

112 This seems to hold true even though the acquisition here antedated the antitrust action by more than thirty years and involved an extremely large portion of du Pont's assets. However, no consolidation had taken place.

113 Compare United States v. E. I. du Pont de Nemours \& Co., 366 U.S. 316 (1961), with the facts of United States v. E. I. du Pont de Nemours \& Co., 351 U.S. 377 (1956).

114179 F. Supp. 721 (E.D. Mo. 1959), prob. juris. noted, 363 U.S. 825 (1960).

115 Id. at 724 n.4. The remedy in Clayton Act $\$ 3$ cases, elimination of the contract, seems less severe than either dissolution or divestiture.

116 Conversely, the nature of the conduct in cases of attempts and conspiracies to monopolize supports inferences clearly unfavorable to the defendants, since specific intent to accomplish the desired end must be shown. See note 51 supra.

117 See United States v. Aluminum Co. of America, 148 F.2d 416, 429-30 (2d Cir. 1945) (dictum).

118 FTC, Rerative Efficiency of Large, Medrum-Sized, and Small Bustness 12-14 (TNEC Monograph No. 13, 1941); Bowman, Toward Less Monopoly, 101 U. PA. L. REV. 577, 590-611 (1953).

119 See Fashion Originators' Guild of America, Inc. v. FTC, 312 U.S. 457, 467 (1941); United States v. Aluminum Co. of America, 148 F.2d 416, 428-29 (2d Cir. 1945). 
corporate mergers and acquisitions," 120 there is no parallel provision interdicting bigness resulting from normal business practices alone until this bigness results in monopoly. ${ }^{121}$

Therefore, in cases of individual monopolization, all of the factors considered tend to justify a broad definition of the market, with its resulting increase in protection for the defendant. For, although such a definition of the market, in which are included physically distinct but functionally interchangeable products, is close to the market as defined by economists, ${ }^{122}$ the administrative difficulties of a full-fledged inquiry into functional interchangeability such as took place in Cellophane might not otherwise be warranted.

Consideration of these same factors leads to a different conclusion in the merger cases. Since the remedy is less severe, the court need not feel the same solicitude for the plight of the defendant. The inferences to be drawn from the conduct are probably less favorable to the defendant. And the general policy of the antitrust laws against greater concentration is reinforced in this area by specific interdictions of combinations, acquisitions, and mergers. It therefore seems proper that the product market be defined for mergers so as to test more strictly their anticompetitive effects. This would usually, but not always, require a more narrowly defined market; ${ }^{123}$ thus a flexible market is required. ${ }^{124}$

There is nothing in the language of the Clayton Act which militates against such a flexible market. The reference to any rather than the line of commerce may even support such a market definition. And it may be suggested that the legislative history of the 1914 act can only be rationally explained by an intention that the relevant market under section 7 should be a flexible one. ${ }^{125}$

This reasoning does not support a judicial abdication permitting, the government to define markets however it may choose in order to lead to the invalidation of all mergers. Erie Sand ${ }^{126}$ indicates that the courts will not accept an FTC definition which is so narrowly drawn that it places fungible products in different markets. Nor is a definition acceptable

120 S. REp. No. 1775, 81st Cong., $2 d$ Sess. 3 (1950).

121 United States v. Swift \& Co., 286 U.S. 106, 116 (1932); United States v. International Harvester Co., 274 U.S. 693,708 (1927); see Únited States v. United States Steel Corp., 251 U.S. 417, 451 (1920); United States v. Aluminum Co. of America, 148 F.2d 416, 430 (2d Cir. 1945).

122 See text accompanying note 39 supra.

123 When the firms seeking to merge are not engaged in an identical line of commerce, a broader market definition will be needed to support a finding of a $\$ 7$ violation. See note 20 supra and accompanying text.

124 Although this reasoning would apply to mergers under both the Sherman and the Clayton Acts, the possibility of criminal penalties may make such flexibility appear offensive under the Sherman Act. However, since the amendment of the Clayton Act in 1950, it is not likely that the Sherman Act's provisions will be resorted to by the FTC or the Justice Department to test the legality of a merger. See Atr'y Gen. NAt'l CoNsM. ANTITRUst Rep. 115 n.1 (1955).

125 See notes 5-20 supra and accompanying text.

126291 F.2d 279 (3d Cir. 1961). 
solely because it is based on the product sold by the merging companies; competitive products must be considered. ${ }^{127}$

Nevertheless, it is unrealistic to assume that there is ever, in any competitive situation, such a thing as "the" market. Several markets may be defined in any case; ${ }^{128}$ invalidation under section 7 should be possible upon proof of a lessening of competition under any one of several reasonable market definitions.

J. N.D.

127 Brillo Mffg. Co., 54 F.T.C. 1905, 1906 (1958).

128 See, e.g., A. G. Spalding \& Bros., Inc. v. FTC, 301 F.2d 585 (3d Cir. 1962); Mytinger \& Casselberry, Inc. v. FTC, 301 F.2d 534 (D.C. Cir. 1962); United States v. Bethlehem Steel Corp., 168 F. Supp. 576 (S.D.N.Y. 1958). 